\title{
Demographics Date of Collection
}

National Cancer Institute

\section{Source}

National Cancer Institute. Demographics Date of Collection. NCI Thesaurus. Code C83026.

The date on which the subject demographics are taken. 